\title{
PROSEDUR PEMBERIAN KREDIT PADA PT. BANK PEKREDITAN RAKYAT (BPR) JORONG KAMPUNG TANGAH (JKT) PARIAMAN CABANG PADANG
}

\author{
Rudi Yasman, Afriyeni \\ Akademi Keuangan dan Perbankan Padang \\ Afriyeni.yen@gmail.com
}

\begin{abstract}
Lending procedures undertaken by the Rural Bank Jorong Kampung Tangah (JKT) Branch Padang Pariaman beginning of the loan process until the loan disbursement. The purpose of this study to understand and find out how the procedure is performed by crediting Rural Bank Jorong Kampung Tangah (JKT) Branch Padang Pariaman. To support this thesis required accurate data. For that the data collected is of secondary data. For a discussion of research methods in the form of data types and sources of secondary data, while the data collection techniques with interviews, library method. The method used is descriptive method. The research location Rural Bank Jorong Kampung Tangah (JKT) Branch Padang Pariaman. The object of study in this research is. Lending procedures undertaken by the Rural Bank Jorong Kampung Tangah (JKT) Branch Padang Pariaman. From the research it can be concluded that the procedure for provision of loans made by the Bank of Rural Jorong Kampung Tangah (JKT) Branch Padang Pariaman. Starting from permohonaan credit by the debtor, identification and credit analysis up to realization. Problems faced by the Bank BPR Jorong Tangah Kampung Padang Pariaman Branch are still many people who do not comply with loan procedures.
\end{abstract}

Keywords: Procedures Lending, Credit Problems

\section{LATAR BELAKANG}

Perbankan mempunyai tugas yang sangat penting dalam rangka mendorong pencapian tujuan nasional yang berkaitan dalam peningkatan dan pemerataan taraf hidup masyarakat dan peningkatan kelangsungan perekonomian Indonesia. Pertumbuhan ekonomi harus diarahkan untuk meningkatkan pendapatan masyarakat serta mengatasi ketimpangan ekonomi dengan kesenjangan sosial. Menurut undang-undang Nomor 10 tahun 1998 tentang perubahan dari UU No 7 tahun 1992 tentang perbankan pengertian bank adalah badan usaha yang menghimpun dana dari masyarakat dalam bentuk simpanan dan menyalurkanya kembali kepada masyarakat dalam bentuk kredit atau bentukbentuk lainya dalam rangka meningkatkan taraf hidup rakyat banyak. 
Bank memiliki fungsi yang sangat penting yaitu fungsi intermediasi keuangan artinya bank disini sebagai perantara dalam menghimpun dana dan menyalurkan dana ke masyarakat. Menghimpun dana dari masyarakat yang berkelebihan dana dan menyalurkan dana kemasyarakat yang kekurangan dana. Menurut perubahan UU No.10 tahun 1998 tentang perbankan : Pengertian Kredit adalah penyediaan dana atau tagihan yang dapat dipersamakan dengan itu, berdasarkan persetujuan atau kesepakatan pinjam meminjam antara bank dan pihak lain yang mewajibkan pihak peminjam melunasi hutangnya setelah jangka waktu tertentu dengan pemberian bunga.

Kredit pada umumnya timbul karena manusia mempunyai kebutuhan dan keinginan untuk menghasilkan atau memperoleh barang dan jasa yang melebihi kemampuan dana yang dimilikinya, agar dapat memenuhi kebutuhan tersebut, maka ia perlu mendapatkan kredit ( pinjaman ) dari pihak-pihak lain baik itu dari orang lain maupun dari lembaga keuangan seperti bank. Salah satu kredit yang diperoleh dari pihak bank berupa kredit komersial.

Dalam penyaluran kredit bank akan menghadapi berbagai macam situasi seperti jika debitur tidak membayar kewajibanya tepat pada waktunya, debitur menghilang dan sebagainya. Oleh karena itu perlu dilakukan pengawasan terhadap pelaksanaan kredit.

Sebelum debitur memperoleh kredit lebih dahulu harus melalui tahapantahapan penilaian yaitu mulai dari permohonan calon debitur, penelitian data oleh bagian kredit, memeriksa kelengkapan data, wawancara, tinjauan langsung kelapangan, analisa kredit, keputusan kredit, perjanjian kredit, dan peningkatan agunan, tahapan-tahapan dalam memberikan kredit ini dikenal sebagai prosedur pemberian kredit. Tujuan pemberian kredit adalah untuk memastikan kelayakan suatu kredit diterima atau ditolak.

PT. Bank Perkreditan Rakyat Jorong Kampung Tangah (JKT) Pariaman Cabang Padang adalah salah satu lembaga keungan yang memberikan fasilitas kredit terhadap masyarakat. Masyarakat dapat memanfaatkan fasilitas layanan ini untuk meminjam uang yang nantinya dapat digunakan sesuai dengan tujuan awal peminjaman. Keberadaan PT. Bank Perkreditan Rakyat Jorong Kampung Tangah (JKT) Pariaman Cabang Padang sendiri sebagai suatu lembaga keuangan yang mempunyai fungsi memberikan pelayanan perbankan dan membantu dalam meningkatkan taraf hidup rakyat masyarakat memberikan manfaat yang besar baik dalam hal penghimpunan dana maupun penyaluran dana kepada masyarakat. Dengan adanya PT. Bank Pekreditan Rakyat Jorong Kampung Tangah (JKT) Pariaman Cabang Padang ini diharapkan dapat memberikan manfaat yang optimal kepada masyarakat dalam rangka meningkatkan taraf hidup rakyat banyak.

Rumusan Masalah

Berdasarkan uaraian latar belakang tersebut maka yang dibahas dalam tugas akhir ini yaitu tentang bagaimana prosedur pemberian kredit pada PT. BPR Jorong kampong Tangah (JKT) Pariaman cabang Padang. 


\section{LANDASAN TEORI}

\section{Pengertian Bank}

Menurut Undang-undang Negara Republik Indonesia Nomor 10 Tahun 1998 Tentang Perbankan, yang dimaksud dengan bank adalah badan usaha yang menghimpun dana dari masyarakat dalam bentuk kredit dan atau bentuk-bentuk lainya yang dalam rangka meningkatkan taraf hidup rakyat banyak.

Menurut undang-undang pokok perbankan nomor 7 tahun 1992 sebagaimana telah diubah dengan undang-undang RI nomor 10 tahun 1998 tentang perbankan maka jenis perbankan terbagi menjadi dua jenis, yaitu

1. Bank Umum

Yaitu bank yang melaksanakan kegiatan usaha secara konvensional dan atau berdasarkan prinsip syariah yang dalam kegiatanya memberikan jasa dalam lalu lintas pembayaran.

2. Bank Perkreditan Rakyat

Yaitu bank yang melaksanakan kegiatan usahanya secara konvensional atau berdasarkan prinsip syariah yang dalam kegiatanya tidak memberikan jasa dalam lalu lintas pembayaran.

\section{Fungsi Bank}

1. Sebagai tempat untuk penitipan atau penyimpanan uang. bank memberikan surat atau selembar kertas dalam bentuk : giro, tabungan dan deposito.

2. Sebagai lembaga pemberi atau penyalur kredit.

3. Sebagai perantara dalam lalu lintas pembayaran.

\section{Pengertian, Fungsi dan Tujuan Pemberian Kredit}

a. Pengertian Kredit

Berdasarkan Undang-undang Perbankan No. 7 tahun 1992 dan telah diperbaharui menjadi Undang-undang No. 10 tahun 1998 adalah penyediaan uang atau tagihan yang dapat dipersamakan dengan itu, berdasarkan persetujuan atau kesepakatan pinjam meminjam antar bank dengan pihak lain yang mewajibkan pihak peminjam melunasi utangnya setelah jangka waktu tertentu dengan pemberian bunganya.

b. Fungsi Pemberian Kredit

1. Untuk meningkatkan daya guna uang.

maksudnya jika uang hanya disimpan saja tidak akan menghasilkan sesuatu yang berguna. Dengan diberikanya kredit uang tersebut menjadi berguna untuk menghasilkan barang atau jasa oleh si penerima kredit.

2. Untuk meningkatkan peredaran dan lalu lintas uang.

Dalam hal ini uang yang diberikan atau disalurkan akan beredar dari satu wilayah ke wilayah lainya sehingga suatu daerah yang kekurangan uang dengan memperoleh kredit maka daerah tersebut akan memperoleh tambahan uang dari daerah lainya.

3. Untuk meningkatkan daya guna barang.

Kredit yang diberikan oleh bank akan dapat digunakan oleh si debitur untuk mengolah barang yang tidak berguna menjadi berguna atau bermanfaat.

4. Meningkatkan peredaran barang.

Kredit dapat pula menambah atau mempelancar arus barang dari satu wilayah ke wilayah lainya sehingga jumlah barang yang beredar dari satu 
wilayah ke wilayah lainya bertambah atau kredit dapat pula meningkatkan jumlah barang yang beredar

5. Sebagai alat stabilitas ekonomi.

Dengan memberikan kredit dapat dikatakan sebagai stabilitas ekonomi karena dengan adanya kredit yang diberikan akan menambah jumlah barang yang diperlukan oleh masyarakat. Kemudian dapat pula kredit membantu dalam mengekspor barang dari dalam negeri ke luar negeri sehingga meningkatkan devisa negara.

6. Untuk meningkatkan kegairahan berusaha.

Bagi sipenerima kredit tentu akan dapat meningkatkan kegairahan berusaha, apalagi bagi si nasabah yang memang modalnya pas-pasan.

7. Untuk meningkatkan pemerataan pendapatan.

Semakin banyak kredit yang disalurkan, akan semakin baik terutama dalam hal meningkatkan pendapatan. Jika sebuah kredit diberikan untuk membangun pabrik, maka pabrik tersebut tentu membutuhkan tenaga kerja sehingga dapat pula mengurangi pengangguran. Di samping itu, bagi masyarakat sekitar pabrik juga akan dapat meningkatkan pendapatanya seperti membuka warung atau menyewa rumah kontrakan atau jasa lainya.

8. Untuk meningkatkan hubungan internasional.

Dalam hal pinjaman internasional akan dapat meningkatkan saling membutuhkan

\section{c. Tujuan Pemberian Kredit}

1. Turut mensukseskan program pemerintah dibidang ekonomi dan pembangunan.

2. Meningkatkan ativitas ekonomi atau kegiatan perusahaan agar dapat menjalankan fungsinya guna menjamin terpenuhinya kebutuhan masyarakat.

3. Memperoleh laba agar kelangsungan hidup bank dapat terjamin mengingat pemberian kredit merupakan kegiatan utama bank dan penghasilan pokok bank.

\section{Prinsip-prinsip Pemberian kredit}

penilaian kredit yang sering dipakai didunia perbankan dikenal dengan prinsip 5C, yang terdiri dari:

1. Character (watak)

Adalah data tentang kepribadian dari calon pelanggan seperti sifat-sifat pribadi, kebiasaan-kebiasaanya, cara hidup, keadaan dan latar belakang keluarga maupun hobinya. Character ini untuk mengetahui apakah nantinya calon nasabah ini jujur berusaha untuk memenuhi kewajibanya dengan kata lain ini merupakan willingness to pay.

2. Capacity (kapasitas)

Merupakan kemampuan calon nasabah dalam mengelola usahanya yang dapat dilihat dari pendidikanya, pengalamanya mengelola usahanya, sejarah perusahaan yang pernah dikelola, capacity ini merupkan ukuran dari ability to play atau kemampuan dalam membayar. 


\section{Capital (permodalan)}

Adalah kondisi kekayaan yang dimiliki oleh perusahaan yang dikelolanya. Hal ini bisa dilihat dari neraca, laporan laba rugi, struktur permodalan, ratio-ratio keuntungan yang diperoleh seperti return of equity, return on investment. Dari kondisi diatas bisa dinalai apakah layak calon pelanggan diberi pembiayaan, dan beberapa plafon pembiayaan yang layak diberikan. 4. Collateral (anggunan / jaminan)

Adalah jaminan yang mungkin bisa disita apabila ternyata calon pelanggan benar-benar tidak bisa memenuhi kewajibanya. Collateral ini diperhitungkan paling akhir, artinya bilamana masih ada suatu kesangsian dalam pertimbangan-pertimbangan yang lain, maka bisa menilai harta yang mungkin bisa dijadikan jaminan.

5. Condition of economic (kondisi ekonomi)

Pembiayaan yang diberikan juga perlu mempertimbangkan kondisi ekonomi yang dikaitkan dengan prospek usaha calon nasabah. Ada suatu usaha yang sangat tergantung kondisi perekonomian, oleh karena itu perlu mengaitkan kondisi ekonomi dengan usaha pelanggan.

Selain 5C diatas, ada juga prinsip lain dalam memberukan kredit yaitu yang biasa disebut $4 \mathrm{P}$ :

\section{Personality}

Bank mencari data tentang kepribadian si peminjam seperti riwayat hidupnya (kelahiran, pendidikan, pengalaman, usaha / pekerjaan dan sebagainya), keadaan keluarga, pergaulan dalam masyrakat serta bagaimana pendapat masyarakat tentang si peminjam, serta hal-hal lain yang erat hubunganya dengan kepribadian si peminjam.

2. Purpose

Mencari dua tentang tujuan atau keperluan penggunaan kredit. Apakah akan digunakanya untuk berdagang, berproduksi atau membeli rumah. Dan apakah tujuan penggunaan kredit itu sesuai dengan line of business kredit bank yang bersangkutan. Misalnya, keperluan / tujuan kredit untuk keperluan perkapalan sedangkan line of business bank justru dalam bidang pertanian.

3. Prospect

Yang dimaksud dengan prospect adalah harapan masa depan dari bidang usaha atau kegiatan usaha si peminjam. Ini dapat diketahui dari perkembangan usaha si peminjam selama beberapa bulan / tahun, perkembangan keadaan eknomi perdagangan, keadaan ekonomi / perdagangan sektor usaha si peminjam, kekuatan keuagan perusahaan yang dibuat dari earning power (kekuatan pendapatan / keuntungan) masa lalu dan perkiraan masa mendatang.

4. Payment

Mengetahui bagaimana pembayaran kembali pinjaman yang diberikan. Hal ini dapat diperoleh dari perhitungan tentang prospek kelancaran penjualan dan pendapatan sehingga dapat diperkirakan kemampuan pengembalian pinjaman ditinjau dari waktu serta jumlah pengembalianya. 


\section{METODE PENELITIAN}

Dalam pengumpulan data dan bahan untuk melakukan penelitian ini,digunakan metode-metode pengumpulan data sebagai berikut:

\section{Metode Pengumpulan Data}

\section{Studi Pustaka (Library Research)}

Penelitian yang dilakukan keperpustakaan, beberapa buku-buku ilmiah dan tulisan-tulisan yang berhubungan dengan pembahasan yang dilakukan.

2. Studi Lapangan ( Field Research)

Penelitian yang langsung ke objek penelitian yang dipilih untuk meneliti hasil data primer, penelitian langsung ke lapangan ini akan dapat membantu penulis untuk melengkapi data yang diperlukan.

\section{Metode Analisis Data}

Dalam menganalisa data, penulis menggunakan analisis data kualitatif sebagai metode penelitian yang menjelaskan secara Deskriptif mengenai aktifitas penghimpunan dan penyaluran dana pada PT. BPR Batang Kapas.

\section{PEMBAHASAN}

\section{Prosedur Pemberian Kredit}

Prosedur pemberian kredit dalam dunia perbankan antara bank yang satu dengan yang lainya sebenarnya sama tidak jauh berbeda. Perbedaanya mungkin hanya terletak pada persyaratanya yang ditetapkan masingmasing bank dan tujuan dari pemberian kredit tersebut. Pada PT. Bank Perkreditan Rakyat Jorong Kampung Tangah (JKT) Pariaman Cabang Padang. Proses pemberian kredit pada nasabah adalah sebagai berikut:

1. Nasabah mengajukan permohonan kredit lengkap dokumen-dokumen pendukung (perizinan, laporan, keuangan, data identitas, akta perusahaan, data penjualan, data agunan, dll).

2. Permohonan tersebut diproses setelah data-data yang diperlukan lengkap. Proses dimulai dengan meminta data informasi debitur secara online ke Bank Indonesia. Melakukan kunjungan ke lokasi usaha, wawancara, dan penilaian agunan.

3. Kemudian dilakukan analisis / penilaian kelayakan kredit 5C oleh petugas analisis kredit berdasarkan data yang telah diperoleh dan hasil kunjungan kelokasi serta wawancara. Analisis tersebut dituangkan dalam suatu laporan penilaian kredit dikenal juga dengan appraisal kredit atau rekomendasi kredit.

4. Apabila usaha dinilai layak oleh analis kredit setelah dilakukan analisis, maka appraisal kredit akan diajukan untuk disetujui oleh pimpinan cabang atau direksi, (tergantung wewenang persetujuan mengacu kepada nominal kredit yang akan dimintakan persetujuanya).

5. Apabila telah disetujui maka diberikan surat pemberitahuan persetujuan kredit (SP2K) kepada nasabah yang mencantumkan syarat-syarat dan ketentuan yang harus dipenuhi oleh nasabah. Jika 
nasabah menyetujui persyaratanya, maka SP2K ditanda tangani oleh nasabah dan diserahkan kembali pada bank.

6. Proses selanjutnya adalah realisasi kredit, peningkatan agunan kredit, dan pencairan kredit.

7. Setelah pencairan kredit dilakukan maka PT. Bank Perkreditan Rakyat Jorong Kampung Tangah (JKT) Pariaman Cabang Padang akan melakukan monitoring terhadap kredit yang telah diberikan tersebut. Monitoring dilakukan dengan cara mengunjungi nasabah, memonitor aktivitas rekening, menelepon nasabah, mencari informasi

\section{Kredit Bermasalah} lain dari rekan nasabah, dll.

Yang dimaksud dengan kredit bermasalah adalah:

1) Kredit yang dalam pelaksanaanya belum mencapai / memenuhi target yang diinginkan oleh pihak bank.

2) Memiliki kemungkinan timbulnya resiko dikemudian hari bagi bank dalam arti luas.

3) Mengalami kesulitan di dalam menyelesaikan kewajiban baik dalam bentuk pembayaran kembali pokoknya dan atau pembayaran bunga, denda keterlamabatan menjadi beban nasabah yang bersangkutan.

Terdapat 2 faktor penyebab kredit bermasalah, yaitu:

a) Faktor intern

a. Analisis kredit atau yang tidak akurat

b. Lemahnya pengawasan dan monitoring

c. Kredit diberikan secara terkonsentrasi baik jumlah maupun penerimanya

d. Lemahnya SDM (Sumber Daya Manusia)

b) Faktor ekstern

a. Nasabah menyalahgunakan kredit yang diperoleh

b. Faktor kesulitan usaha yang di alami nasabah

Penyelesaian kredit bermasalah:

a) Upaya yang dilakukan secara adminitrasi adalah nasabah diberi surat tunggakan, surat peringatan I, Surat II, dan Surat III.

b) Selain itu dilakukan penagihan langsung kepada nasabah atau pemilik agunan, maka proses dilanjutkan dengan meminta bantuan penagihan dari pihak lain seperti kejaksaan.

c) Jika belum ada penyelesaian konkrit dari pihak nasabah atau pemilik agunan, maka proses dilanjutkan dengan meminta bantuan penagihan dari pihak lain seperti kejaksaan.

d) Jika nasabah bersedia dapat dilakukan penjualan agunan dibawah tangan untuk menyelesaikan kreditnya.

e) Jika nasabah tidak bersedia jual agunan dibawah tangan maka langkah terakhir adalah dengan melakukan pelelangan agunan kredit untuk penyelesaian tunggakan kredit bermasalah. 


\section{SIMPULAN}

1. Prosedur pemberian kredit pada PT. BPR Jorong Kampung Tangah diawali dengan permohonan calon debitur, selanjutnya petugas kredit mengidentifikasi data calon nasabah apakah ditolak atau diterima, dan apabila permohonan kredit diterima pihak bank akan mempertimbangkan untuk dilanjutkan dengan menganalisa kelengkapan data calon nasabah, selanjutnya pihak bank akan meninjau langsung ke lokasi tempat usaha calon nasabah, selanjutnya petugas kredit menganalisa kredit setelah mengumpulkan data dan informasi nasabah, apakah disetujui atau tidak disetujui, jika tidak disetujui maka bank akan memberikan surat penolakan dan surat permohonan akan dikembalikan ke nasabah, sebaliknya jika disetujui calon nasabah akan diberi surat persetujuan kredit oleh bagian kredit, kemudian membuat perjanjian kredit dan peningkatan agunan atau jaminan.

2. Tujuan prosedur pemberian kredit adalah untuk memastikan kelayakan suatu kredit, diterima atau ditolak. Dalam menentukan kelayakan suatu kredit maka dalam setiap tahap selalu dilakukan penilaian yang mendalam.

\section{DAFTAR PUSTAKA}

Alanshari, F., \& Marlius, D. (2018). Prosedur Pemberian Kredit KPR Pada PT. Bank Tabungan Negara (Persero) TBK Cabang Pembantu Bukittinggi. https://doi.org/10.31227/osf.io/rsfhc

Amelia, L., \& Marlius, D. (2018). Pengendalian Kredit Dalam Upaya Menciptakan Bank Yang Sehat Pada PT. Bank Pembangunan Daerah Sumatera Barat Cabang Utama Padang. https://doi.org/10.31227/osf.io/kpc64

Andriani, B., \& Susanto, R. (2019). Pengawasan Kredit PT. Bank Perkreditan Rakyat (BPR) Ophir Pasaman Barat. https://doi.org/10.31219/osf.io/aunvc

Baiya, \& Fernos, J. (2019). Analisis Faktor-Faktor Penyebab Kredit Macet Pada Bank Nagari Cabang Siteba. https://doi.org/10.31227/osf.io/4xuks

Darmawanto, \& Fernos, J. (2019). Prosedur Pemberian Kredit Pada Bank Nagari Cabang Sijunjung. https://doi.org/10.31227/osf.io/psqfy

Firmansyah, A., \& Fernos, J. (2019). Analisis Kredit Bermasalah Dilihat Dari Standar Non Performing Loan (NPL) Pada PT. Bank Perkreditan Rakyat (BPR) Prima Mulia Anugrah Cabang Padang. https://doi.org/10.31227/osf.io/gcj94 
Ikbal, M., \& Marlius, D. (2017). Pengaruh Jumlah Taksiran Dan Uang Pinjaman Terhadap Laba Bersih Pada PT. Pegadaian (UPC) Gurun Laweh. https://doi.org/10.31227/osf.io/uch4a

Orlando, A., \& Susanto, R. (2019). Mekanisme Pencairan Kredit Usaha Rakyat Pada PT. Bank Rakyat Indonesia Unit Lubuk Buaya. https://doi.org/10.31219/osf.io/zuv2y

Pratama, D., \& Fernos, J. (2019). Prosedur Pelaksanaan Kredit Usaha Rakyat (KUR) Pada PT. Bank Nagari Cabang Padang. https://doi.org/10.31227/osf.io/ag68j

Widayati, R. (2019). Penyelesaian Kredit Bermasalah Pada PT. Bank Perkreditan Rakyat (BPR) Nagari Kasang. https://doi.org/10.17605/OSF.IO/D4MF3

Widayati, R. (2019). Pelaksanaan Prinsip Kehati-Hatian Dalam Pemberian Kredit Konsumtif Pada Bank Nagari Cabang Siteba. https://doi.org/10.17605/OSF.IO/FZVXR

Widayati, R. (2019). Aktivitas Pemberian Kredit Komersil Pada Bank Nagari Cabang Sijunjung. https://doi.org/10.17605/OSF.IO/QTVZ9

Widayati, R. (2019). Pelaksanaan Kredit Pada Bank Perkreditan Rakyat LPN Pasar Baru Durian Sawahlunto. https://doi.org/10.17605/OSF.IO/5HPAB 